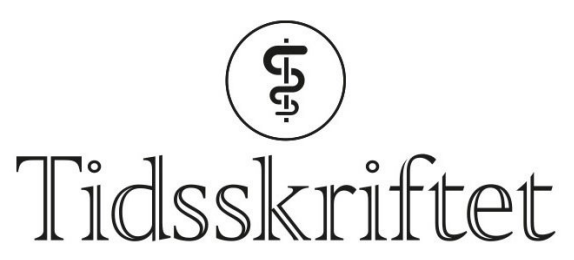

DEN NORSKE LEGEFORENING

\title{
Hva skal ambulansearbeidere med høyskoleutdanning kalles på norsk?
}

SPRÅKSPALTEN

\section{OLE KRISTIAN VÅGE}

E-post: ole.vage@sprakradet.no Ole Kristian Våge er ph.d., seniorrådgiver i Språkrådet og medlem av Gruppe for norsk medisinsk fagspråk.

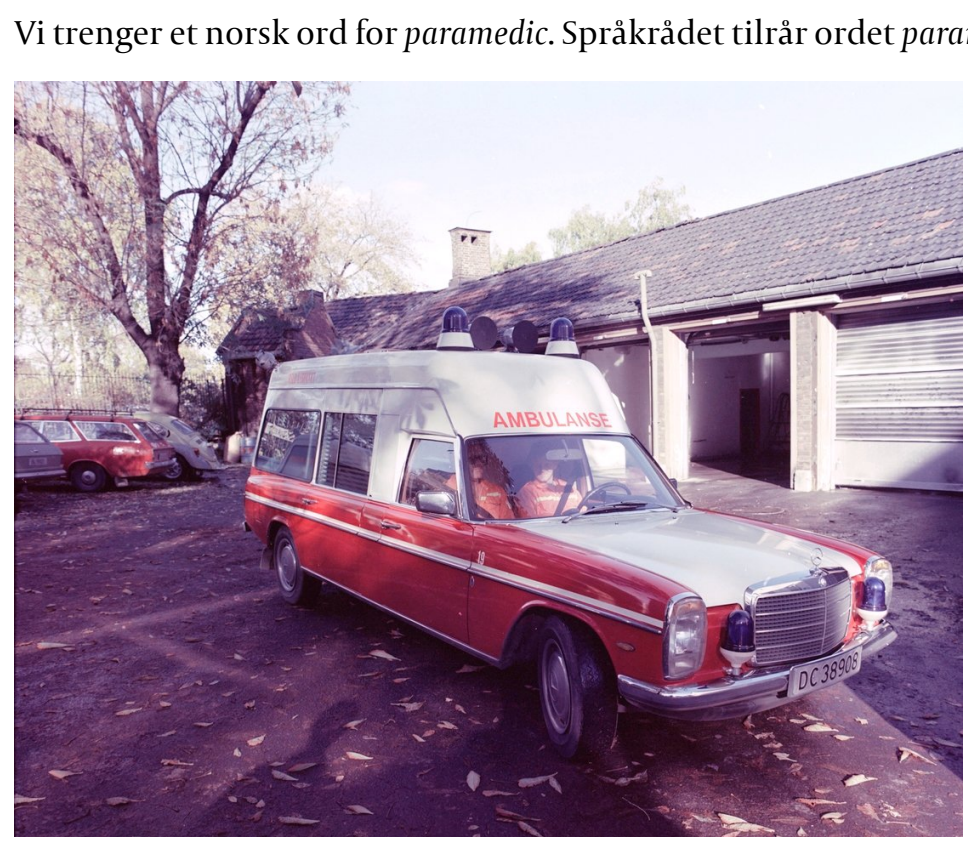

Mercedes-ambulanse utenfor garasjen ved Oslo legevakt i 1977. Foto: Leif Ørnelund, Oslo Museum / Byhistorisk samling (CC BY-SA 4)

Språkrådet har fått flere henvendelser om hva paramedic bør hete på norsk. I Oxford Dictionary of English blir begrepet definert som «a person who is trained to do medical work, especially emergency first aid, but is not a fully qualified doctor» (1). Man kunne tenke seg norske avløsere som ambulansearbeider, akuttmedisiner, paramedik, paramediker og paramedisiner. Språkrådet tilrår sistnevnte.

Ambulansepersonell i Norge har tradisjonelt ikke hatt krav om høyskoleutdanning, men det er nå blitt opprettet bachelorutdanning for ambulansearbeidere ved flere høyskoler og universiteter (2). Slike ambulansearbeidere har av mange fått den engelske tittelen paramedic. Ordet paramedic ble først brukt i norske avistekster om norske forhold i 2002, men slo igjennom i 2008 med 35 avisomtaler (3). Da var paramedic allerede blitt brukt i norske fagtekster og rapporter siden 1998 (4). Tittelen paramedic er imidlertid språklig 
uheldig, for det gir oss bøyningsrekken paramedic - paramedicen - paramedicer-paramedicene i norsk. Det engelske ordet passer ikke helt inn i det norske formverket, for c-bokstaven gir normalt en s-lyd før e. Den engelske ordsammensetningen er dessuten ikke spesielt selvforklarende. Det bør finnes et velfungerende alternativ på norsk, og mange etterlyser nettopp det.

Man kunne selvsagt velge å norvagisere ordet til paramedik, slik det er gjort i Medisinsk ordbok (5). Ordet er derimot ikke kommet i bruk på norsk og har tydeligvis ikke særlig appell blant språkbrukerne. Et søk i mediearkivet Retriever gir heller ingen treff. Samtidig vil det tenkte personsuffikset -ik plassere paramedik i selskap med fyllik og sullik. Det kan lett bøtes på ved å legge til det tradisjonelle suffikset -er,paramediker, som er noe i bruk, med seks treff i mediearkivet Retriever i trykte aviser. Ulempen ved begge kandidatene er at det blir vanskelig å lage gode adjektivavledninger. Paramediksk og paramedikersk ville neppe passere en språklig konsultasjonstime.

Andre, også i Tidsskriftet, har tatt i bruk ordet paramedisiner, og et søk i mediearkivet Retriever gir ti treff, inkludert bøyningsformene, i trykte aviser. Paramedisiner er en kandidat med flere språklige fordeler. Ordet følger tradisjonell orddanning ved at man tar utgangspunkt i et fagfelt eller en fagpraksis (paramedisin) og legger til suffikset-er for å vise yrkesutøveren. Ordet er sånn sett skodd over samme lest som allmennmedisiner, indremedisiner, samfunnsmedisiner osv. Fagfeltet paramedisin blir i Medisinsk ordbok forklart som «medisinsk praksis utøvd av person som ikke er lege, f.eks. sykepleie, fysioterapi, dietetikk, radiografi og vernepleie» (6). Paramedisin blir derimot andre steder knyttet til alternativ behandling som ikke bygger på skolemedisinsk grunnlag, og begrepet kan da få en negativ konnotasjon for enkelte (7). Det er også en ulempe at paramedisin kan gi uheldige assosiasjoner til parapsykologi og det paranormale.

Likevel er bruken av ordet paramedisin om kvalifisert førstehjelp nokså etablert i Norge. I Paramedisinsk håndbok fra 1974 blir paramedisiner brukt om alt sideordnet helsepersonell, inkludert ambulansemannskap, brannmannskap og politi (8). Det kan hevdes at betydningen i dag er blitt innsnevret til først og fremst å gjelde ambulansemannskap som har tatt paramedisinsk høyskoleutdanning. Profesjonaliseringen har altså gitt en semantisk endring. Det samme har også skjedd med det engelske begrepsparet paramedicine/paramedics. I Oxford English Dictionary står følgende oppført under paramedical: «Associated with or related to medicine or the medical profession; spec. designating or relating to fields considered to be allied or auxiliary to medicine, such as physiotherapy, social work, etc.; designating or relating to workers in such fields. More recently also: of, relating to, or designating emergency medical personnel» (9).

Noen læresteder omtaler faget som prehospitalt arbeid (10). Det er en ordsammensetning som det er vanskelig å lage nyttige avledninger av. Begrepet omfatter nok også mer enn det vi vil betegne som faget til paramedisinere.

Noen bruker ambulansearbeider for paramedic, men det er ikke helt treffende siden ordet er reservert for yrkesutøvere med videregående opplæring. Alternativet akuttmedisiner bygger på akuttmedisin, som er medisinsk praksis ved akuttmottakene ved sykehus og legevakt $\mathrm{i}$ tillegg til ambulansetjeneste. Akuttmedisiner blir derfor for upresist, og det er vel neppe $\emptyset$ nskelig å la betydningen bare gjelde for den aktuelle yrkesgruppen. Dessuten kan det også gi inntrykk av at vedkommende er lege - en medisiner er synonym for lege.

Språkrådet mener derfor at ambulansepersonell med bachelorutdanning bør kalles paramedisinere. 
2. Utdanning til ambulansearbeider.

https://delta.no/yrke/ambulanseforbundet/utdanning-til-ambulansearbeider (2.10.2017).

3. Paramedic. I mediearkivet Retriever. http://web.retriever-info.com/services/archive/search (12.10.2017).

4. Norges offentlige utredninger. Hvis det haster... Faglige krav til akuttmedisinsk beredskap. NOU 1998: 9. https://www.regjeringen.no/no/dokumenter/nou-1998-9/id141301/(12.10.2017).

5. Paramedik. I: Nylenna M, red. Medisinsk ordbok. www.ordnett.no/search?languageno\&phraseparamedik (8.8.2017).

6. Paramedisin. I: Nylenna M, red. Medisinsk ordbok. www.ordnett.no/search?languageno\&phraseparamedisin (8.8.2017).

7. Bruset S. Paramedisin (2.5.2016). I: Store medisinske leksikon. sml.snl.no/paramedisin (8.8.2017).

8. Moe J, red. Paramedisinsk håndbok: moderne livreddende og skadebegrensende hjelp ved ulykker og akutt sykdom. Oslo: Teknologisk forlag, 1974: 5 .

9. Paramedical. I: Oxford English Dictionary. www.oed.com/view/Entry/137513 (25.8.2017).

10. Prehospitalt arbeid - paramedic. Høgskolen i Oslo og Akershus.

www.hioa.no/Studier-og-kurs/HF/Bachelor/Prehospitalt-arbeid-paramedic (2.10.2017).

Publisert: 12. desember 2017. Tidsskr Nor Legeforen. DOI: 10.4045/tidsskr.17.0755

(C) Tidsskrift for Den norske legeforening 2020. Lastet ned fra tidsskriftet.no 